\title{
Two Speiropsis species (Anamorphic Fungi- Hyphomycetes) from Bahia State, Brazil
}

\author{
Fabio Fernandes Barbosa ${ }^{1,3}$ and Luís Fernando Pascholati Gusmão
}

Received: December 05, 2003. Accepted: December 07, 2004

\begin{abstract}
RESUMO - (Duas espécies de Speiropsis (Fungo Anamórfico - Hyphomycetes) do Estado da Bahia, Brasil). Durante o levantamento de microfungos associados a folhas em decomposição de plantas nativas do Estado da Bahia, duas espécies de Speiropsis foram encontradas: S. pedatospora Tubaki e S. scopiformis Kuthub. \& Nawawi. São apresentadas descrições, ilustrações, comentários, distribuição geográfica e uma tabela comparativa das características taxonômicas das espécies de Speiropsis. S. pedatospora constitui primeira referência para o Brasil.
\end{abstract}

Palavras-chave: biodiversidade, microfungos, taxonomia

ABSTRACT - (Two Speiropsis species (Anamorphic Fungi - Hyphomycetes) from Bahia State, Brazil). During a survey of the microfungi associated with dead leaves of native plants in the State of Bahia, two species of Speiropsis were found: S. pedatospora Tubaki and S. scopiformis Kuthub. \& Nawawi. Descriptions, illustrations, comments, geographical distribution and a compared table with taxonomic characteristics of the Speiropsis species are present. S. pedatospora is the first record for Brazil.

Key words : biodiversity, microfungi, taxonomy

\section{Introduction}

The genus Speiropsis was erected by Tubaki (1958) from a single species S. pedatospora Tubaki, found on dead leaves of Eriobotrya japonica (Thunb.) Lindl. (Rosaceae) in Japan. Speiropsis contains species that produce erect, simple, straight, septate, mononematous or, in a few species, aggregated in fascicles or synnematous to sporodochial conidiophores with discrete, denticulate, polyblastic conidiogenous cells and catenate conidia in branched or unbranched chains connected by narrow isthmi.

According to Keshava Prasad \& Bhat (2002), this genus have nine species, S. aquatica Aramb., Cabello \& Megascini (Arambarri et al. 1987), S. belauensis Matsush. (Matsushima 1985), S. hyalospora Subram. \& Lodha (Subramarian \& Lodha 1964), S. irregularis R.H. Petersen (Petersen 1963), S. ixorae Subram. \& Sudha (Subramarian \& Sudha 1986), S. pedatospora Tubaki (Tubaki 1958), S. scopiformis Kuthub. \&
Nawawi (Kuthubutheen \& Nawawi 1987), S. simplex Matsush. (Matsushima 1971) and S. rogergoosensis Kesh. Prasad \& Bhat (Keshava Prasad \& Bhat 2002). However, S. irregularis was transferring to Arbusculina irregularis (R.H. Petersen) Marvanová \& Descals (Marvanová \& Descals 1987). The genus Speiropsis is considered an aquatic Hyphomycetes by some authors (Tubaki et al. 1983; Marvanová \& Descals 1987) and it has a tropical and subtropical distribution. A synopsis with morphological features and geographical distribution of the described Speiropsis species are given in Tab. 1.

In Brazil, S. scopiformis was collected by first time associated with leaf litter of Miconia cabussu Hoehne (Melastomataceae) in the Atlantic Rain Forest, State of São Paulo (Gusmão et al. 2001).

This contribution comprises the occurrence of $S$. pedatospora and S. scopiformis found in a Mangrove and "Campo Rupestre" area, respectively, in the State of Bahia.

\footnotetext{
1 Universidade Federal da Bahia, Instituto de Biologia, Rua Barão de Geremoabo, s/n, Campus de Ondina, CEP 40170-290, Salvador, BA, Brasil

2 Universidade Estadual de Feira de Santana, UEFS, Departamento de Ciências Biológicas, C. Postal 252, CEP 44031-460, Feira de Santana, BA, Brasil (lgusmao@uefs.br)

3 Corresponding Author: fbarbosa@ufba.br; ffbarbosa_fungi@yahoo.com.br
} 
Table 1. Comparison of the taxonomic characteristics and geographical distribution of the described Speiropsis species.

\begin{tabular}{|c|c|c|}
\hline Species & Morphological features & Geographical distribution \\
\hline S. aquatica & $\begin{array}{l}\text { Conidia unbranched; conidial chains } 6-7 \text { cells, } \\
40-50 \times 2.6-3 \mu \mathrm{m}\end{array}$ & Argentine \\
\hline S. belauensis & $\begin{array}{l}\text { Conidia unbranched; conidial chains } 5-7 \text { cells, } \\
40-60 \times 4-5 \mu \mathrm{m}\end{array}$ & Palau \\
\hline S. hyalospora & $\begin{array}{l}\text { Conidia branched, developing in } 3 \text { divergent chains, } \\
8-10 \times 3.5-5 \mu \mathrm{m}\end{array}$ & Sri Lanka \\
\hline S. ixorae & $\begin{array}{l}\text { Conidia unbranched; conidial chains } 5-6 \text { cells, } \\
33.5-46.5 \times 2.8-3.3 \mu \mathrm{m}\end{array}$ & India \\
\hline S. pedatospora & $\begin{array}{l}\text { Conidia branched, developed in 3-4 divergent chains, } \\
10-14 \times 4-7 \mu \mathrm{m}\end{array}$ & $\begin{array}{l}\text { USA (Hawai), Japan, Solomon Islands, } \\
\text { Sri Lanka,Taiwan, Brazil }\end{array}$ \\
\hline S. scopiformis & $\begin{array}{l}\text { Conidia unbranched; conidial chains } 5-7 \text { cells, } \\
40-65 \times 2-3 \mu \mathrm{m}\end{array}$ & Brazil, Malaysia, Cuba, New Caledonia \\
\hline S. simplex & $\begin{array}{l}\text { Conidia unbranched; conidial chains } 7-9 \text { cells, } \\
80-110 \times 4-5 \mu \mathrm{m}\end{array}$ & Papua New-Guinea, México \\
\hline S. rogergoosensis & $\begin{array}{l}\text { Conidia branched; developed in many divergent chains, } \\
4-6 \times 1-2 \mu \mathrm{m}\end{array}$ & India \\
\hline
\end{tabular}

\section{Material and methods}

Dead leaves were collected and used as substrate for the isolation of the anamorphic fungi. The washing technique with twenty serial changes of sterile distilled water was applied to the leaves (Harley \& Waid 1955). Leaf fragments were transfered to moist chambers at room temperature for development of reproductive structures, conidiophores and conidia. Identification was made based on slide mountings prepared with PVL resin (alcohol polyvinylic and lactophenol) and cotton-blue (Trappe \& Schenck 1982). Details of fungal characteristics were studied, measured, described and illustrated. Permanent slides were deposited in the "Herbário da Universidade Estadual de Feira de Santana" (HUEFS).

\section{Results and discussion}

1. Speiropsis pedatospora Tubaki, J. Hattori Bot. Lab. 20: 171.1958.

Fig. 1-2.

Conidiophores macronematous, mononematous, simple, straight or flexuous, 4-7 septate, solitary, smooth, brown, $104-147 \times 3.5-5 \mu \mathrm{m}$. Conidiogenous cells polyblastic, determinate, discrete, cylindrical, denticles not evident, smooth, light brown, $8-12 \times$ 4-6 $\mu \mathrm{m}$. Conidia catenate connected by narrow isthmi with 4-8 cells, forming branched chains, 65-80 $\mu \mathrm{m}$, cylindrical to cuneiform, smooth, pale to mid-brown, $10-11.5 \times 3.5-5 \mu \mathrm{m}$.
Brazilian material has smaller conidia than those described in the literature (Tubaki 1958). However, this variation is probably influencied by the substract and habitat. The conidia of Digitodochium rhodoleucum Tubaki \& Kubono and Cladoconidium articulatum Bandoni \& Tubaki resemble that of S. pedatospora in gross morphology (Tubaki \& Kubono 1989). The conidial chains of $S$. pedatostopora are similar to $S$. hyalospora and $S$. rogergoosensis, but the morphology and dimensions of the conidiophores and the disposition of conidial branched chains distinguish these species. S. pedatospora is recorded in Brazil for the first time

Material examined: BRAZIL. Bahia: Conde, 22/IX/2001, on dead leaves of Laguncularia racemosa (L.) C.F. Gaertn. (Combretaceae), Barbosa (HUEFS 56702).

2. Speiropsis scopiformis Kuthubutheen \& Nawawi, Trans. Br. mycol. Soc. 89: 584. 1987.

Fig. 3-4.

Conidiophores macronematous, mononematous, simple, straight or flexuous, 1-3-septate, solitary, smooth, brown, $28-90 \times 4-5.5 \mu \mathrm{m}$. Conidiogenous cells polyblastic, integrated, discrete, clavate to lageniforme, usually with 2-3 denticulate projections in the apical region, smooth, light brown, 6.5-8.5×3-6 $\mu \mathrm{m}$. Conidia catenate connected by narrow isthmi with $5-7$ cells forming unbranched chains $37-51 \mu \mathrm{m}$, smooth, hyaline to light brown; intermediary conidia cylindrical, $6-8.5 \times$ 2-2.5 $\mu \mathrm{m}$; terminal conidia cuneiform, 6-7.5 $\times 1.5-2.5 \mu \mathrm{m}$. 
The description provided by Mouchacca (1990) and Gusmão et al. (2001) corresponds to our species, however, conidiophores are smaller when compared with description provided by Kuthubutheen \& Nawawi (1987) and Keshava Prasad \& Bhat (2002). $S$. scopiformis resemble $S$. aquatica and S. ixorae, but the number of cells in the conidial chain and the dimensions of the conidiophores distinguish these species.

Material examined: BRAZIL. Bahia: Palmeiras, 24/VI/2000, on dead leaves of Cupania paniculata Cambess. (Sapindaceae), Gusmão (HUEFS 56671); Seabra, 23/VI/2000, on dead leaves of Senna rizinii H.S. Irwin \& R.C. Barneby (Caesalpiniaceae), Gusmão (HUEFS 56689); Rio de Contas, 20/IV/2001, on dead leaves of Miconia pepericarpa DC (Melastomataceae), Gusmão (HUEFS 56573).

The differences among collecting areas reveal the plasticity of this genus in colonizing different hosts and it is probable that this genus is more representative in other Brazilian ecosystems.

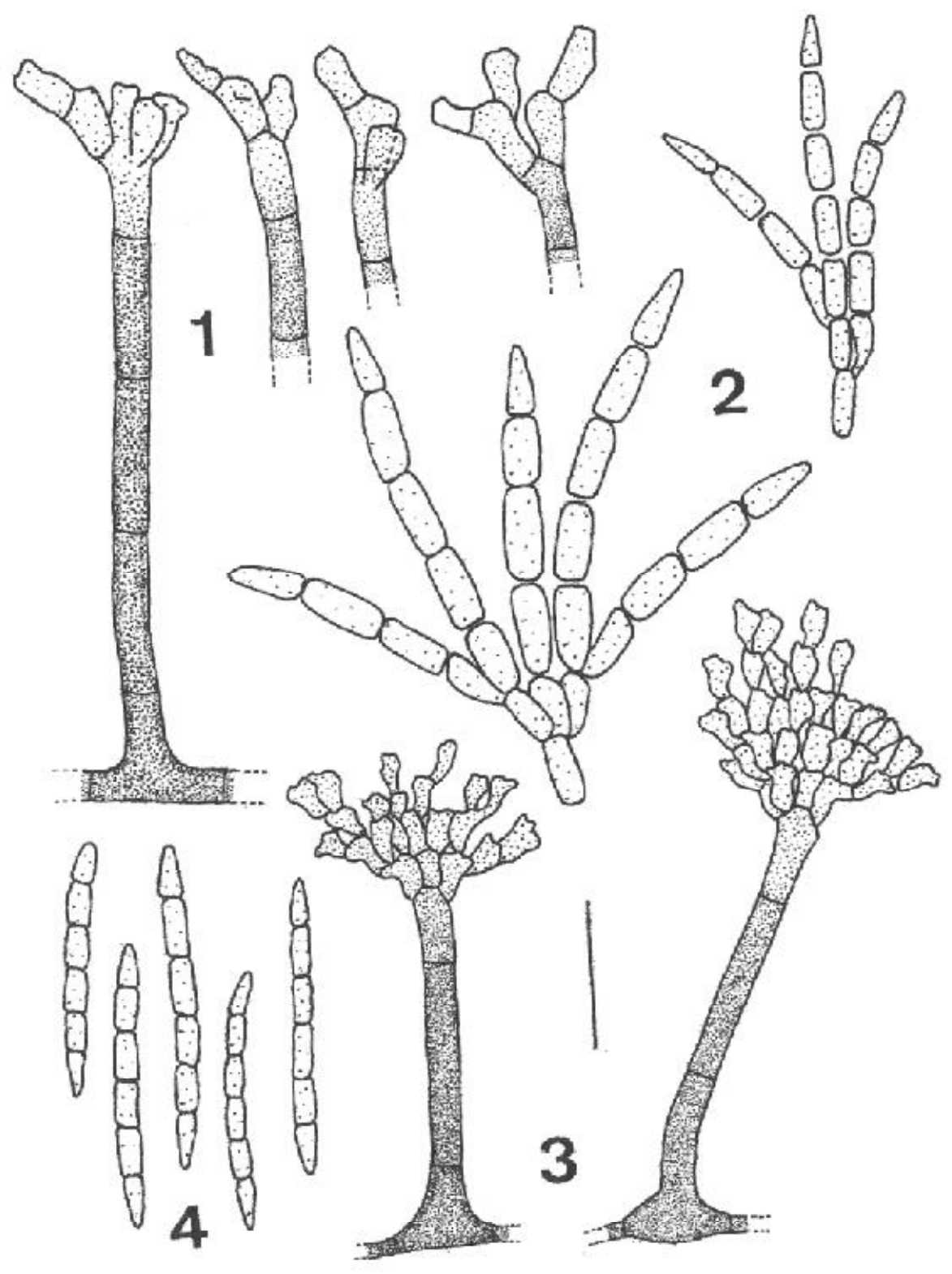

Figures 1-2. Speiropsis pedatospora Tubaki. 1. Conidiophore with conidiogenous cells. 2. Branched conidia. Figures 3-4. Speiropsis scopiformis Kuthub. \& Nawawi. 3. Conidiophores with conidiogenous cells. 4. Unbranched conidia. Bar: $25 \mu \mathrm{m}$. 


\section{Acknowledgement}

The first author wishes to acknowledge CAPES (Coordenação de Aperfeiçoamento de Pessoal de Nível Superior) for providing his grant. The authors are grateful to "Programa Flora da Bahia" for facilities during expeditions in the "Campo rupestre" vegetation.

\section{References}

Arambarri, A.; Cabello, M. \& Megascini, A. 1987. Estudio sistematico de los Hyphomycetes del Rio Santiago. II. Boletín de la Sociedad Argentina de Botánica 25: 213-222.

Gusmão, L.F.P.; Grandi, R.A.P. \& Milanez, A. I. 2001. Hyphomycetes from leaf litter of Miconia cabussu in the Brazilian Atlantic Rain Forest. Mycotaxon 79: 201-213.

Harley, J.L. \& Waid, J.S. 1955. A method of studying active mycelia on living roots and other surfaces in the soil. Transactions of the British Mycological Society 38: 104-118.

Keshava Prasad, T.S. \& Bhat, D.J. 2002. Speiropsis rogergoosensis sp. nov. from India. Mycotaxon 82: 127-131.

Kuthubutheen, A.J. \& Nawawi, A. 1987. A new species of Speiropsis from Malaysia. Transactions of the British Mycological Society 89: 584-587.

Marvanová, L. \& Descals, E. 1987. New taxa and new combinations of aquatic Hyphomycetes. Transactions of the British Mycological Society 89: 499-507.
Matsushima, T. 1971. Mycological reports from New Guinea and Solomon Islands 7. Interesting Fungi Imperfect. Bulletin of the Natural Science Museum, Tokyo 14: 460-480.

Matsushima, T. 1985. Matsushima Mycological Memoirs 4. Publish by the author. Kobe.

Mouchacca, J. 1990. Champignons de Nouvelle-Calédonie I. Quelques Dématiées intéressantes de litiére forestière. Persoonia 14: 151-160.

Petersen, R.H. 1963. Aquatic Hyphomycetes from North America. II. Aleuriosporae (part 2), and Blastosporae. Mycologia 55: 18-29.

Subramanian, C.V. \& Lodha, B.C. 1964. Two interesting Hyphomycetes. Canadian Journal of Botany 42: 1057-1063.

Subramanian, C.V. \& Sudha, K. 1986. Hyphomycetes from leaf litter-II. Kavaka 14: 37-40.

Trappe, J.M. \& Schenck, N.C. 1982. Taxonomy of the fungi forming endomycorrhizae. Pp. 1-9. In: N.C. Schenck (ed.). Methods and principles of micorrhizae research St. Paul, The American Phytopathological Society.

Tubaki, K. 1958. Studies on the Japanese Hyphomycetes V. leaf and stem group with discussion of the classification of Hyphomycetes and their perfect stages. Journal of the Hattori Botanical Laboratory 20: 142-244.

Tubaki, K. \& Kubono, T. 1989. Digitodochium, a new staurosporous anamorph genus. Sydowia 41: 344-348.

Tubaki, K.; Watanabe, K. \& Manoch, L. 1983. Aquatic Hyphomycetes from Thailand. Transactions of the Mycological Society of Japan 24: 451-457. 